INTERNATIONAL ECONOMIC PROBLEMS 


\section{International \\ Economic Problems}

\section{LEONARD GOMES}

Middlesex Polytechnic

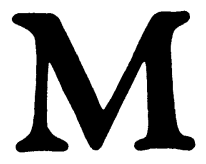


(C) Leonard Gomes 1978

Reprint of the original edition 1978

All rights reserved. No part of this publication may be reproduced or transmitted, in any form or by any means, without permission.

First published 1978 by

THE MACMILLAN PRESS LTD

London and Basingstoke

Associated companies in Delhi Dublin

Hong Kong Johannesburg Lagos Melbourne

New York Singapore and Tokyo

British Library Cataloguing in Publication Data

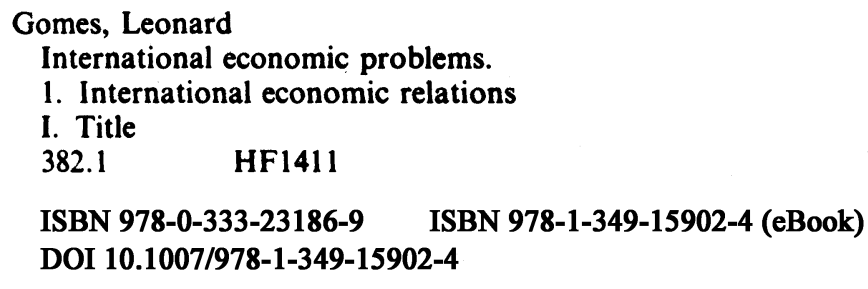

This book is sold subject to the standard conditions of the Net Book Agreement.

The paperback edition of this book is sold subject to the condition that it shall not, by way of trade or otherwise, be lent, re-sold, hired out, or otherwise circulated without the publisher's prior consent in any form of binding or cover other than that in which it is published and without a similar condition including this condition being imposed on the subsequent purchaser. 


\section{Contents}

List of Tables vii

Preface $\quad$ ix

Acknowledgements $\quad$ xi

INTRODUCTION

1 Multilateral Trade Negotiations 7

1.1 The Progress of Trade Liberalisation 7

1.2 Non-Tariff Barriers 19

1.3 Agricultural Protectionism 25

2 Trade and Debt Problems of the Third World 31

2.1 Expansion of Industrial Exports 31

2.2 Commodity Problems 45

2.3 LDC Debts 56

3 EAst-West Trade 63

3.1 The Background 63

3.2 East-West Trade Problems $\quad 70$

3.3 Prospects 74

4 The Eurodollar Market, Short-Term Capital Flows ANd Currency Crises $\quad 80$

4.1 Rationale of the Eurodollar Market 81

4.2 The Eurodollar Market and Monetary Policy in Europe 85

4.3 Currency Crises $\quad 92$

5 World Monetary Arrangements 100

5.1 The Bretton Woods System 100

5.2 The 1971 Dollar Crisis and its Aftermath 106

5.3 Perspectives on International Monetary
Reform 
vi Contents

6 Multinational Corporations 118

6.1 The Significance of the Multinational Corporation

118

6.2 Multinationals and Development 127

6.3 Policies towards Multinationals 136

7 Technology, Human Resources And InterNATIONAL COMPETITION

7.1 Labour Skills and Comparative Advantage 143

7.2 Technology and Trade Patterns 152

7.3 Indices of Competitiveness 159

Notes and References $\quad 165$

Index 


\section{List of Tables}

1.1 Average Level of Customs Duties After the Kennedy Round (per cent)

1.2 Industrial Import Quotas in Major Countries, 1970

1.3 Agricultural Import Quotas in Major Countries, 1970

2.1 Imports of Manufactures by 21 Developed Countries from Developing Countries, 1962, 1973

2.2 Leading Developing Country Exporters of Manufactures, 1970, 1972

2.3 Industrial Tariff Profiles in Selected Major Industrial Countries

2.4 Trade Creation Effects of Tariff Cuts and Quantitative Limitations Under the GSP Schemes (1971 data, in thousand U.S. dollars)

2.5 Estimated External Debts of Selected non-OPEC LDCs, end 1975 (data in \$ billions)

3.1 Trade of Industrial Western Countries with COMECON, 1975

3.2 Value of COMECON Countries' Exports to the West, 1975

3.3 East-West Trade as Percentages of Total Trade of COMECON Countries, 1973

4.1 Growth of the Eurocurrency Market, 1965-77 Net Size (billions of U.S. dollars)

4.2 Estimated Disposition of OPEC Surpluses (in billions of U.S. dollars)

5.1 U.S. Liabilities to Foreign Official Institutions, by Area, 1968-75 (in millions of dollars)

5.2 Growth Rates of Consumer Prices and Money Stock-Six Industrial Countries, 1965-74 (per cent change; annual rate) 
viii List of Tables

6.1 Stock of Foreign Direct Investment (book value) held by Major Countries, 1967 and 1971

6.2 Distribution of Japan's Foreign Direct Investment by Industrial Sector and Region (in millions of U.S. dollars and percentage end 1973) 


\section{Preface}

This book was designed to meet the need for a policy or problem-orientated text to complement an introductory theory text in the field of international economics. General texts, more often than not, treat international policy issues in a rather cursory fashion. This book remedies this deficiency by offering the student and the general reader an up-to-date, comprehensive and critical analysis of the keenly debated issues in international economic relations. Its purpose is to bridge the gap between the abstractions of economic theory and the complexity of economic decision-making and policy. By providing concise statements of the major problems confronting the world economy it serves as a source of topics for essays or project work assigned to students who have mastered the basic theory.

A theme that runs throughout the book is the clash of national interests against the constraints imposed on national policy-making by the inexorable trend towards interdependence in the world economy. This problem is specifically treated in the Introduction, but its undertones can be discerned in subsequent chapters. Chapter 1 discusses the issues involved in the current Tokyo Round of multilateral trade negotiations. This is followed by chapters on the trade problems of the Third World and an analysis of the new frontiers in East-West trade. The integration of money markets across the Atlantic and, indeed, financial integration in the wider world is the subject of Chapter 4, which examines the role of the Eurodollar market in this development. Chapter 5 looks at the problems of the international monetary system and discusses the failures and achievements of the post-war IMF system established at Bretton Woods - a system designed to institutionalise monetary co-operation as a permanent feature of international economic relations. Nowhere (apart from the area of com- 


\section{x Preface}

mercial policy) is the tension between international interdependence and national sovereignty more acute than in the sphere of international monetary arrangements. The conflicts that brought down the Bretton Woods system are described, as are the attempts to rebuild a new monetary order. The impact of multinational corporations on the world economy is the topic of Chapter 6. The book ends with a survey of recent empirical and theoretical explanations of the pattern of international trade in manufactured goods. An understanding of the underlying forces in trade patterns is appropriate in the context of the trade liberalisation and adjustment measures now currently being discussed in the Tokyo Round.

In all the discussions the findings of the very latest research are incorporated.

Throughout the text references to 'billion' = United States billion, i.e. 1 thousand million.

LEONARD GOMES 


\section{Acknowledgements}

The author and publishers wish to thank the following organisations who have kindly co-operated in granting permission to quote tabular matter published by them:

The Bank for International Settlements, Basle.

General Agreement on Tariffs and Trade, Geneva.

The International Monetary Fund, Washington, D.C.

The Ministry of International Trade and Industry, Japanese Government.

The Morgan Guaranty Trust Company of New York.

The United Nations.

The United Nations Conference on Trade and Development.

Every effort has been made to trace all copyright-holders, but if any have been inadvertently overlooked the publishers will be pleased to make the necessary arrangement at the first opportunity. 